\title{
ПРОБЛЕМИ СОЦІАЛЬНОГО ПРОГРЕСУ В СУСПІЛЬНО-ПОЛІТИЧНІЙ ТА ФІЛОСОФСЬКІЙ ДУМЦІ УКРАЇНИ У ДОСЛІДЖЕННЯХ УКРАЇНСЬКОГО РАДЯНСЬКОГО ФІЛОСОФА - ОЛЕКСАНДРА ЛИСЕНКА
}

\begin{abstract}
Анотація. В статті на основі сучасного сцієнтизму, здійснено дослідження наукового спадку українського радянського фрілософра О. Лисенка. За допомогою застосування методів системного, компаративного та контент-аналізу було визначено основні напрями досліджень, систематизовано й охарактеризовано ідейно-теоретичні та методологічні установки, ціннісні й політико-ідеологічні уподобання, що у підсумку дало можливість визначити дослідницьку позицію вченого. Головним завданням О. Лисенка було детальне вивчення проблем соціального прогресу, як однієї з корінних проблем філософської науки та дослідження цього питання в історії фрілософрської думки України. Вчений здійснив критичний аналіз окремих концепцій і теорій історико-філософської науки, провів їхню переоцінку у відповідності до рівня тогочасного наукового знання. Особливу актуальність дане дослідження має для здійснення теоретично виваженого осмислення складної історії фрілософської та суспільно-політичної думки на Україні, а також допоможе поглибити знання про українську філософську культуру та філософську традицію радянського періоду.
\end{abstract}

Ключові слова: О. Лисенко, соціальний прогрес, науково-технічна революція, українська фрілософрська думка, Київська світоглядно-гносеологічна школа.

Yarmolitska Nataliia, Moskalchuk Maryna

Taras Shevchenko National University of Kyiv

\section{THE PROBLEM SOCAIL PROGRESS IN THE SOCIAL-POLITICAL AND PHILOSOPHY THOUGHT UKRAINE IN THE RESEARCH OF THE UKRAINIAN SOVIET PHILOSOPHER - OLEKSANDER LYSENKO}

Summary. In the article on based on modern scientism, a study of the scientific heritage of the ukrainian soviet philosopher O. Lysenko was carried out. Using the methods of systematic, comparative and content analysis, the main directions of research were identified, ideological-theoretical and methodological attitudes, value and political-ideological preferences were systematized and characterized, which eventually made it possible to determine the research position of the scientist. The main task O. Lysenko was detailed study of the problems of social progress, as one of the fundamental problems of philosophical science and the study of this issue in the history of philosophical thought in Ukraine. The special place in the scientific heritage O. Lysenko occupied the question of the spiritual culture of man in the modern scientific-technological revolution. O. Lysenko's main achievement was his research of Ukrainian philosophical thought. The scientist rethinks in a new way the influence of prominent figures and thinkers of the second half of the XIX century on the development of advanced public opinion on Ukraine. O. Lysenko tried to convey to the general public that the theoretical idea of progress did not stand still, it moved on the path of truth, it had undoubted achievements that met the objectives of the liberation movement, and sometimes these ideas grew into complete concepts, became a logical continuation of previous progressive views on the historical process, as well as associated with the achievements of economic and spiritual freedom. Also in his research, O. Lysenko made a critical analysis of certain concepts and theories of historical and philosophical science, re-evaluated them in accordance with the level of scientific knowledge of the time. This study is especially relevant for the implementation of a theoretically balanced understanding of the complex history of philosophical and socio-political thought in Ukraine, as well as help to deepen knowledge about Ukrainian philosophical culture and philosophical tradition of the Soviet period.

Keywords: O. Lysenko, social progress, scientific-technological revolution, ukrainian philosophical thought, Kyiv worldview-epistemological school.

$\Pi^{2}$ остановка проблеми. 3 плином часу відходять в далечінь забуття наукові здобутки вчених минулого століття, яких можна сміливо віднести до першопрохідців на шляху пошуків нових теоретичних рубежів в науці. Тому, перед сучасними істориками науки стоїть найважливіше завдання - відтворювати картину минулого в усьому його різноманітті суперечливих реалій, без прикрас і упереджень. Тому, загальною метою даного дослідження є поглиблене знання радянської фрілософрії та історії суспільно-політичної й фрілософрської думки на Україні. А основними цілями дослідження $є$ реконструкція наукових пошуків О. Лисенка, теоретична модель основних етапів їх розвитку в українській радянській фрілософрії XX ст., роз'яснення ключових проблем, на які була спрямована увага вченого, опис основних напрямів і особливостей його наукових розвідок здійснених в радянський період. Також одним з важливих завдань даного дослідження $€$ опис та аналіз методології дослідження та розуміння наукової спадщини радянських фрілософів. Для цього основна увага буде зосереджена на вивченні наукової спадщини українського радянського фрілософра - О. Лисенка, зважаючи на те, що цій проблемі було присвячено незначна 
кількість праць. Більше того, навіть серед сучасної фрілософрської літератури вивчення наукового спадку цього вченого зустрічається досить рідко і має побіжний характер. Цей фракт, на нашу думку, є аргументом для значущості та актуальності даного дослідження для сучасних наукових досліджень в області вивчення історії фрілософрської думки на Україні в радянський період.

Аналіз останніх досліджень i публікацій. Важливо відмітити, що системне вивчення української фрілософрської думки радянського періоду має чималий багаж наукових досліджень. Все частіше сучасні науковці звертаються до малодосліджених творчих та наукових напрацювань українських радянських фрілософрів другої половини XX ст. Зазначимо, що більшість сучасних вітчизняних дослідників зосереджуються на вивченні окремих аспектів розвитку фрілософрської думки, осмисленню особливостей світоглядної ситуації в радянській Україні, серед них слід виділити праці Г. Аляева, І. Бичка, В. Горського, В. Свдокименка, С. Йосипенка, П. Йолона, І. Огородника, С. Пролеєва, М. Поповича, С. Руденка, М. Русина В. Табачковського та ін. Однак системне вивчення окремих постатей української фрілософрської думки радянського періоду розпочато нещодавно й має деякі прогалини, які досі залишаються невивченими і мало відомими. Тому автори даної статті звертаються до дослідження наукового спадку представника Київської світоглядно-гносеологічної школи - О. Лисенка, 3 подальшим викладом його основних напрацювань і відповідною оцінкою наукових здобутків вченого.

Виклад основного матеріалу. В запропонований статті міститься аналіз наукової діяльності Олександра Якимовича Лисенка (1925-1990) профресора Київського державного університету імені Т.Г. Шевченка, який належав до вчених, які своїми науковими пошуками розірвали блокаду досліджень видатних вітчизняних особистостей і зробили істотні кроки в напрямі нових трактувань ідейних процесів на Україні. Підтвердженням цього стали опубліковані праці О. Лисенка, які були присвячені дослідженню соціально-фрілософрських проблем науково-технічного прогресу, філософрській і суспільно-політичній думщі України та багато інших [1]. Він належав до тієї формації вчених, зусиллями яких в другій половині XX ст. було не тільки завершено формування цілісної матеріалістичної концепції в науці, але й здійснена спроба вийти за межі успадкованого з минулого ідеологізованого варіанту наукових досліджень.

Характеризуючи наукову діяльність О. Лисенка, дощільно виділити основні їі етапи, які взаємопов'язані одним завданням, але є специфічними за способом та формами їх реалізації. Насамперед, це стосується дослідження вченим проблеми соціального прогресу, яку він вважав однією 3 корінних проблем фрілософрської науки, і яка є особливо складною в історії фрілософрської думки. Історико-фрілософрська наука, вважав О. Лисенко, як і будь-яка наука взагалі, не може розвиватись без критичного аналізу окремих концепцій і теорій, їхньої переоцінки у відповідності до рівня сучасного наукового знання, без постановки нових проблем. Також, потребують подаль- шого дослідження й питання духовної культури людини в умовах соціального прогресу [1].

О. Лисенко належав до числа вчених, чия діяльність підготувала радикальні зміни в історико-фрілософрській думщі України, які в подальшому вплинули на розвиток історико-фрілософрських досліджень. Коло його наукових інтересів визначилось в кінці 50-х рp. ХХ ст. У цей період О. Лисенко зосереджується на дослідженні того, яке значення для розвитку науки і техніки в суспільному прогресі мали російські революціонери-демократи Чернишевський, Писарєв, природодослідники - I. Сєченов, I. Мечников, Д. Менделєев, а також видатні представники української революційної демократії - Т. Шевченко, І. Франко, С. Подолинський. О. Лисенко наводить приклад 3 «Щоденника» Т. Шевченка, в якому можна знайти уривки в яких поет високо цінуе значення наукових відкриттів, він писав про те, що майбутне належить паровій машині, яка покликана змінити світ. Так, С. Подолинський вважав, що розвиток науки дозволить колосально примножити штучними засобами кількість тієї природної енергії, яка вже існує й намагався пов'язати соціальний прогрес 3 науково-технічним прогресом, з його удосконаленням, завдяки техніці та знаряддям праці. С. Подолинський розумів, що «наступ техніки, - це процес об’ективний» [3, с. 16-17]. Однак, відмічав О. Лисенко, в історії передової суспільної думки на Україні одне з найпомітніших місць у вирішенні питання про співвідношення соціального і наукового прогресу належало I. Франку, який вже тоді дивився далеко вперед, висловивши плідну думку про те, що науковий прогрес може, як прискорювати так і гальмувати історичний процес [3, с. 17-18].

Досліджуючи історію передової суспільної та фрілософрської думки України, О. Лисенко доводить, що вона нерозривно пов'язана з історією спільної боротьби українського та російського народів проти зовнішніх ворогів, самодержавства та капіталізму. Вивчаючи історію розвитку революційно-визвольної боротьби в Росії та на Україні в останній чверті XIX ст., вчений підкреслював, що ця боротьба проходила під загальним підйомом української національної культури. В цей період виокремлюеться цілий ряд революційних суспільних діячів - письменників і мислителів, серед яких перше місце належало великому українському письменнику і мислителю I. Франку [4, с. 3]. Навколо оцінки творчості та діяльності якого завжди йшла гостра боротьба, навіть ще за його життя. Як зазначав О. Лисенко, «українські буржуазні націоналісти намагались вихолостити револющійний зміст 3 творчості українського письменника, принизити його роль в розвитку передової української та світової культури. Тільки марксисти-ленінці змогли дати справжню вірну оцінку діяльності та світогляду I. Франка» [4, с. 4].

Щодо таких висловлювань О. Лисенка, то тут слід відмітити, що вони свідчать про те, що вчений на початку своєї наукової діяльності перебував в межах метанарації марксизму-ленінізму, які превалювали в наукових дослідженнях радянських науковців протягом 50-80-х рр. $\mathrm{XX}$ ст., й повністю закінчились тільки після розпаду СРCP. 
Приділяючи значну увагу дослідженню соціологічних поглядів I. Франка та розуміння письменником закономірностей суспільного розвитку, О. Лисенко, основуючись на марксистськоленінській методології, показуе яку роль відіграв I. Франко в історії фрілософрської думки України. Він характеризуе письменника, як матеріаліста та атеїста, який стояв на рівні досягнень природознавства свого часу. Вся творчість і революційна діяльність I. Франка була тісно пов'язана 3 визвольною боротьбою українського народу в Галичині та Східній Україні. На такі погляди письменника, стосовно народно-визвольної боротьби в західноукраїнських землях, вплинула революція 1905 р. в Росії [4, с. 5-6]. Посилення визвольної боротьби на Україні і в Росії стало для I. Франка стимулом для додаткового вивчення передової суспільної та фрілософрської думки не тільки Росії, а й Західної Свропи. Тому, зазначає О. Лисенко, письменник детально вивчає російську матеріалістичну фрілософрію, еволюційну теорію Дарвіна, а також російську літературу. «Твори російських револющіонерів демократів допомогли Франку розібратись у складних явищах суспільного життя... Як матеріаліст Франко вів рішучу боротьбу з позитивізмом і схоластикою в науці, буржуазним естетством та містикою в літературі» [4, с. 6]. В таких працях як «Критичні листи про галицьку інтелігенцію», «Література, iï призначення та найважливіші риси», «Наука та її відношення до трудящих мас» I. Франко викладає свої фрілософрські погляди. Однак, як зазначав О. Лисенко, найбільш повно письменник розкривається як матеріаліст в праці «Думки про еволюцію в історії людства", в якій він пояснюе закономірності розвитку природи, підкреслює нерозривність фрілософії та природничих наук, показує яке значення має природознавства для матеріалізму. Матеріалістично вирішуючи основне питання фрілософіï I. Франко зазначав, «що природа є єдиним матеріальним цілим; в природі відбувається безперервний рух, безперервний процес народження та вмирання. Рух мільярдів атомів стали за певних умов причиною утворення незліченних світів. Дотримуючись космогонічної теорії Канта та Лапласа, Франко стояв на рівні наукових досягнень свого часу в питанні виникнення сонячної системи» [4, с. 7].

О. Лисенко звертає увагу на те, що пояснюючи різних явища природи та суспільного життя, I. Франко використовуе діалектику. Він критикуе вчених, які метафізично розглядають явища природи, без врахування їхньої едності та взаємного зв'язку. Письменник зазначав, що «діалектика міститься в усіх речах і явищах дійсності... діалектика являе собою «природну причинність внутрішнього розвитку», вона «таїть в собі протиріччя... й 3 найрізноманітніших частин створює цілісне уявлення про світ» [4, с. 7]. Такими своїми поглядами, зазначає О. Лисенко, I. Франко у вирішенні питання про пізнання об'єктивного світу, впритул підходить до діалектичного матеріалізму. Він розглядає розвиток та удосконалення людського розуму, як здатність сприймати та вірно відображати об'єктивний світ.

Іншим питанням, піднятим О. Лисенком під час дослідження спадку I. Франка було те, що письменник виступив противником ототожнен- ня законів природи із законами суспільного життя. Він критикуе «соціальний дарвінізм» та реакційну теорію Мальтуса про народонаселення. Як зазначав О. Лисенко, I. Франко зумів побачити пряму залежність класової боротьби в суспільстві від майнової нерівності та різкого розділення людей на касту багатих і касту бідних. «Близьке до марксистського розуміння класової боротьби в суспільстві давало Франку можливість зробити вірні револющійні висновки про необхідність боротьби народу за своє звільнення, про неминучу перемогу революції» [4, с. 10]. Однак, вважав О. Лисенко, висловлюючи ряд вірних та глибоких думок про майбутне суспільства, I. Франко все ж не зміг піднятись до марксизму в питанні про соціалізм. Иому не вдалося провести чіткого розмежування між утопічним та науковим соціалізмом, він не зміг зрозуміти закономірностей соціалістичної революції та необхідності диктатури робочого класу. Це стало свідченням того, що письменник переоцінив роль просвітительської діяльності в справі визвольної боротьби та встановлення нового суспільного ладу.

Однак, О. Лисенко звертає увагу і на позитивні моменти в творчості І. Франка, які проявились в тому, що спираючись на конкретний історичний матеріал письменник висловив вірну думку про те, що не окремі особистості, а народ, ступінь його активності в суспільному житті, визначають історичний прогрес. За визначенням I. Франка теорї та ідеї, які висували окремі особистості, не можуть істотно вплинути на хід історії, якщо для цього не підготовлена відповідна основа, і якщо народ байдужий до цих теорій та ідей. Він вважав, що нероздільність суспільства на ворожі прошарки є історично невірною. I. Франко робить спроби розвінчати нащіоналістичну «теорію» про безбуржуазність, безкласовість української нації. Для цього він спирається на історичні факти, які підтверджували протилежність економічних i політичних інтересів трудящих мас і буржуазії. Загалом, робить висновок О. Лисенко, І. Франко був поборником возз'єднання українських земель. Однак, і в національному питанні український письменник не завжди був вільним від національної обмеженості, були у нього й окремі помилки $[4$, с. 12$]$.

Слід зазначити, що О. Лисенко високо оцінив суспільно-політичну, літературну та наукову діяльність I. Франка, вважав її прикладом палкого патріотичного служіння народу, борця за світле майбутнє, переконання якого стали близькими і дорогими всім народам, всьому прогресивному людству [4, с. 13].

Важливо підкреслити, що у фрілософрській літературі радянського періоду були стилістичні та наукові кліше, які були пов'язані з суспільним та державним життям того часу, і яким зобов'язані були слідувати науковці у своїх дослідженнях. У даному контексті продовжував свої дослідження проблем сощіального прогресу і О. Лисенко. Він вважав, що особливо складним це питання є в історї фрілософрської думки, а саме при визначенні критерію прогресу відповідно до кожної історичної епохи. «Матеріальні та духовні блага, прагнення до гармонійного розвитку, е обов'язковою кінцевою метою діяльності людей, яка досягаеться в складній взаємодії, яка часто не піддається негайній роз- 
шифрровці суспільних сил, і обов'язок науки - знайти, спираючись на досвід історії та враховуючи гірку оману минулого, найбільш доцільний шлях розвитку суспільства і людини» [5, с. 3]. О. Лисенко намагається спростувати тезу про те, що починаючи 3 60-х pp. XIX ст. і аж до широкого розповсюдження марксистської ідеології в Росії та Україні, в поглядах на шлях револющйного перетворення суспільства відбувався повний застій. Безумовно, зазначає вчений, деякий спад теоретичної думки мав місце, однак не слід ігнорувати досить значимі досягнення в області соціології в 70-80-х рр. XIX ст., а також зв'язку з народно-визвольним рухом цього періоду.

Слід відмітити, що О. Лисенко не тільки критикував існуючі буржуазні концепції прогресу, він також підкреслював і окремі позитивні моменти. Свідченням цього були «прогресивні для свого часу ідеї Сен-Сімона, Гердера, Гегеля про безперервний, поступальний розвиток суспільства, які досить швидко замінюються в середині XIX ст. теоріями гармонійного розвитку буржуазного суспільства «як нормального стану» (О. Конт), ідеями встановлення "рівноваги в суспільстві» (Г. Спенсер) i «прагнення до солідарності між різними соціальними верствами» (М. Ковалевський) [5, с. 8]. Такі ідеї, зазначає О. Лисенко, мали певний світоглядний вплив на демократичну соціологічну думку другої половини XIX ст. Вони яскраво проявились в українській думці, в якій більшість мислителів проблеми прогресу розглядали, виходячи з благотворного впливу марксизму, і в різній мірі проявляли пильну увагу й до деяких буржуазних теорій прогресу.

Однак, на наш погляд, найбільш вагомим досягненням О. Лисенка було його досить детальне дослідження історії виникнення та розвитку демократичних ідей прогресу на Україні. А здійснений вченим аналіз концепцій прогресу, став визначним історичним етапом в розвитку фрілософрського знання про істину. Одними з перших представників на Україні, на кого звернув увагу в своїх дослідженнях О. Лисенко, і які мали позитивні моменти в поглядах на прогрес, на його історичний процес, були М. Костомаров і М. Ковалевський. Саме вони дали свою трактовку соціального прогресу. Загалом, за визначенням О. Лисенка, погляди М. Костомарова носили ліберально-буржуазний напрямок. Мислитель неодноразово відмічав у своїх працях, що народ, його політичні права повинні бути предметом уваги справжніх істориків та соціологів. М. Костомаров був одним 3 перших істориків Україні, який звернувся до дослідження витоків «народовладдя", причин народних рухів, вказав на економічні передумови існування класів та соціальних верств. У М. Ковалевського критерій соціального прогресу був спрямований на загальнокультурний рівень народу, який складався в результаті взаємодії різних економічних і духовних фракторів, які діяли об'єктивно та виражались самостійно в кожній країні. В кінці-кінців така взаємодія, вважав він, приведе суспільство до «соціальної гармонії», солідарності державних, правових та інших суспільних інститутів 3 інтересами народу [5, с. 18-19].

О. Лисенко відмічав, що визначальне значення на становлення передової суспільної дум- ки в 70-80-ті рр. в Росії та на Україні мали ідеї О. Конта та Г. Спенсера. До цих ідей звертались С. Подолинський, I. Франко, М. Павлік, М. Драгоманов. Вони належали до передової, на той час, суспільної думки, яка використовувала «окремі позитивні моменти еволюційної теорії, як раз там де вони ігнорувались представниками буржуазно-ліберального табору» [5, с. 15-16]. О. Лисенко вважав, що механістичний еволющіонізм не міг стати кроком вперед у розвитку фрілософрської та соціологічної думки, а тому швидко застарів у зв'язку з ломкою старих природничо-наукових уявлень та змінами, що стались у соціально-економічній структурі капіталізму в кінці XIX ст. Тому, представники передової соціологічної думки України в питаннях про шляхи соціального прогресу шукали вихід, застосовуючи критичне переосмислення ідей О. Конта і Г. Спенсера. Однак, зазначає О. Лисенко, хоча ці пошуки проходили в руслі матеріалістичної традиції, в теоретичній сдері вони зіткнулися з традиціями, які були пов'язані, головним чином, з нерозробленістю діалектичного методу у вітчизняній dpiлософріï та соціології [5, с. 16].

Серед видатних вітчизняних постатей, які намагались знайти загальні закономірності у розвитку природи та суспільства, вміння науково просувати важливі соціальні зміни в суспільстві до сучасних реалій, О. Лисенко відмічає представника револющійно-демократичної думки XIX ст. - C. Подолинського. Значним кроком в розвитку науки було те, що С. Подолинський розробив питання про вирішальну роль праці в розвитку суспільства. Він не вважав, що будьяка праця є основою прогресу, однак намагався знайти ті ланки, які з'єднають людську діяльність 3 природними процесами. За його визначенням основою прогресу є праця великих колективів, «громад», які об'єднують людей за певним виробничим принципом, в основі якого лежить суспільне розділення праці. Таким чином С. Подолинський був схильним вважати, що розділення праці є першоосновою зміни суспільно-економічних формацій, хоча, як відмічає О. Лисенко, ще не застосовував цей термін у своїх працях [5, с. 22]. Таким чином, поставивши проблему «людина - природа - праця - суспільство», С. Подолинський, в цілому, пішов вірним шляхом у вирішенні цього питання. «Його теорія праці, як примноження та збереження існуючої природної енергії була проривом у ще недослідженій області науки яка стосувалась кардинальних питань суспільного розвитку, які необхідно було вирішувати в комплексі 3 найновітнішими досягненнями природничих наук” [5, с. 25]. Таким чином, підкреслював О. Лисенко, можна стверджувати, що теорія сощіального прогресу С. Подолинського була побудована на досягненнях суспільних наук того часу та спиралась на конкретний аналіз соціально-економічних відносин в Росії та на Україні.

Однак, О. Лисенко був переконаний, що найбільш повне вираження концепції соціального прогресу революційно-демократичного напряму, в суспільній думщі на Україні, найкраще простежуеться в творчості I. Франка, який відкрив новий етап у розвитку української національної культури. $\mathrm{Y}$ цьому питання особлива роль 
I. Франка полягає в постановці та вирішенні питання про спадкоемність (послідовність) в історії. Письменник вважав, що дотримання принципу послідовного характеру розвитку суспільства дає можливість сощіологу побачити приховані в глибині явища зв'язку між минулим і сьогоденням, а також в загальних рисах уявити картину майбутнього [5, с. 26]. Як, зазначає О. Лисенко, I. Франко вперше в історії української суспільної думки вводить в науку поняття «єдиного суспільного організму», який об'єднує більшість людей в трудові колективи, а меншість - в касту, яка живе працею цієї більшості. І. Франко намагається знайти причини занепаду процвітаючих раніше цивілізацій і приходить до висновку, що вони криються у «використанні нікчемною меншістю людей досягнення матеріальної та духовної культури». Він висловлює думку про суперечливий характер технічного прогресу, який може не тільки прискорювати, але й сповільнювати суспільний розвиток в залежності від того, кому він служить: більшості або меншості [5, с. 27]. I. Франко приходить до ще одного висновку про те, що історичний процес-це явище об'єктивне і закономірне. Не заперечуючи значення для поступального розвитку суспільства передових суспільних ідей, мислитель бачить першопричину соціального прогресу не в природі людини, а в матеріальних, економічних або «майнових» фракторах. Проте, зазначає О. Лисенко, на початку творчої діяльності I. Франка у його поглядах переважала антропологічна тенденція в поясненні суспільних явищ.

О. Лисенко вважав, що схожими на погляди I. Франка в пошуках загальних контурів руху історії та з'ясуванню того, що сприяе цьому руху, були наукові пошуки М. Драгоманова. Звідси можна говорити про близьке до матеріалістичного розуміння М. Драгомановим історії пояснення причин прогресу і потребами суспільства в соціальних змінах. Однак, як відмічав О. Лисенко, сильною стороною поглядів М. Драгоманова на прогрес було розуміння ним суперечливого характеру розвитку капіталізму в Західній Європі та Росії. «Він прямо вказував на винахідливість та спритність в експлуатації "найманих рабів» тим класом, який колись проголошував «свободу та рівність для всіх», на вміння цього класу використовувати створені «народною працею» машини в своїх власних інтересах» [5, с. 33]. М. Драгоманов був переконаний, що шляхи здійснення прогресу в історії полягають в необхідності ломки старих порядків, за допомогою мирних та немирних форм такої ломки, однак надавав перевагу тим 3 них, які вимагають «найменших жертв». В кінці життя мислитель схилявся до започаткування рефрорм, завдяки яким народ зможе поступово повернути те, що раніше йому належало. М. Драгоманову належить визначення поняття «еволюції», під яким слід розуміти цілий комплекс соціальних змін, які мастять корінні зміни в усьому суспільному організмі [5, с. 34].

Слід зазначити, що О. Лисенко бачив існування протиріч в поглядах М. Драгоманова, які прослідковувались між сміливим загально-соціологічним висновком мислителя про закономірний характер соціального прогресу, життевою защікавленістю в ньому нових суспільних сил, а з іншого боку, надмірною інколи обережністю в його практичному здійсненні [5, с. 34]. Однак, зазначає О. Лисенко, знайти діалектичну єдність національного та соціального, розгледіти вирішення національного питання в ході соціалістичної революції М. Драгоманову було не під силу. I якщо на початку наукової діяльності він писав про те, що «прогрес цивілізаціі обумовлений перш за все силою наукової, політичної та моральної свідомості», а в кінці 70-х рр. говорить про працю як вирішальний фрактор поступального розвитку суспільства, і на початку 90-х рр. стверджуе, що «головний мотор соціального руху - це економічний прогрес, вільна праця і фрілософрія», розуміючи під фрілософрією передові ідеї суспільства» [5, с. 36]. Однак, О. Лисенко відмітив, що не дивлячись на таку невизначеність, думки М. Драгоманова про прогрес та його рушійну силу мали велике суспільне значення та сприяли визвольному руху в країні.

Багато цікавого про історичний процес, класову боротьбу, революції, антинародний характер існуючих політичних та правових інститутів, ворожість прогресу релігії та церкви, О. Лисенко знаходить досліджуючи творчість українського публіциста М. Павліка. Він був нетерпимим до будь-яких форм сощіального гніту, гостро реагував на злободенні питання суспільного життя, гаряче закликав до "негайного бунту», що в значній мірі сприяло усвідомленню визвольної боротьби українського народу. Так само, як і на I. Франка, на формування світогляду М. Павліка вплинуло знайомство 3 робочим рухом на Заході та з виступами робітничого класу Галичини. Невипадково М. Павлік в своїх ранніх статтях заявляв про свою прихильність до матеріалізму. Під прогресом публіцист часто застосовував ідентичний термін «поступ», розуміючи рух суспільства «вперед, а не назад», зростання матеріального та загальноосвітнього рівня народу в цілому, звільнення його від влади релігії «здорової за своєю природою свідомості», однак вважав, що останне слово в цьому питання повинна сказати наука, яка протягом століть підкопувала та розхитувала всі релігії - давні та сучасні» [5, с. 41].

Як і більшість публіцистів того часу, констатує О. Лисенко, М. Павлік згодом переглянув свої погляди на перетворення суспільства шляхом "масового народного бунту", він схиляеться до роботи з організації усіх демократичних сил, закликає до політичної просвіти неграмотного галицького християнства. Він рішуче переглядає свою позицію в питанні про терористичний метод боротьби 3 соціальною несправедливістю, вважаючи, що такий метод є «помилковим шляхом соціальної помсти» [5, с. 43]. 3 90-х pp. М. Павлік стає прихильником введення всезагального виборчого права, виступає за ліквідацію постійної армії, вважає необхідною демократизацію шкільної освіти аж до відокремлення школи від церкви. Ці та інші думки М. Павліка знайшли великий суспільний резонанс серед трудящих Галичини. О. Лисенко вважав, що такі зміни в поглядах М. Павліка свідчили про його інтернаціоналістичні переконання, про його мрії створення єдиної польсько-української народної демократичної партії, він виступав проти національної винятковості, в якій, перш за все, зацікавлені імущі класи [5, с.44]. Як політичний діяч 
та активний учасник визвольного руху М. Павлік був близький до матеріалістичного розуміння історичного процесу, був на рівні передової суспільної думки про прогрес. Він ставив на перше місце соціальні проблеми, вбачаючи в них відповідь на питання, яким чином можна покращити важку долю народу [5, с. 45].

Зосереджуючись на вивченні української суспільно-політичної та фрілософрської думки XIX ст. О. Лисенко виокремлюе постать видатного українського публіциста та економіста - М. Зібера. Він був популяризатором марксизму, видатним вченим-економістом і соціологом, який піднявся до вірного соціально-економічного аналізу суспільних явищ, послідовно відстоював економічне вчення Маркса. Економічні дослідження М. Зібера так чи інакше торкались багатьох актуальних питань історичного процесу, він вивчав подальші шляхи розвитку суспільства. У властивій йому манері конкретного аналізу М. Зібер вивчає розвиток поредорменої Росії. I хоча справжнім марксистом він не став, однак, як запевняв О. Лисенко, намагався бути на рівні прогресивних ідей суспільного розвитку, шукав відповіді на теоретичні та практичні проблеми перед якими постане суспільство через двадцять, тридцять років після падіння кріпосного права [5, с. 47]. Як соціолог М. Зібер намагався матеріалістично вирішувати основне питання суспільного розвитку - «про первинність суспільного буття по відношенню до суспільної свідомості, виділяв і підкреслював вирішальну роль матеріального виробництва в житті. Матеріальні, економічні відносини, на думку Зібера, визначали духовну сфреру діяльності людей... I для минулого, i для теперішнього, і майбутнього прогрес міститься в розвитку матеріального виробництва й тих відносинах, які йому сприяють... Прогрес об'єктивний процес, який ніколи не припиниться, говорив Зібер» [5, с. 48]. Він вказував на фрактори, які так чи інакше гальмують прогрес - це капіталістична експлуатація, прагнення до отримання прибутку, використання техніки в корисливих цілях. Існуюча система господарства, як і розділення добування продукту, зжили себе і повинні бути замінені новою організацією праці та їі новим розподілом [5, с. 50]. Такі погляди М. Зібера підтримувала й поділяла револющійно налаштована молодь, яка в ті роки робила перші кроки до розвитку соціального прогресу.

Дослідницький діапазон та аналітичний погляд нового підходу О. Лисенка до вивчення розвитку ідей соціального прогресу на Україні в 70-80-х pp. XIX ст., охоплював широку проблематику, в якій чільне місце зайняли дослідження, зроблені видатним економістом і соціологом демократичного спрямування В. Навроцьким. Як вчений, відмічав О. Лисенко, В. Навроцький відрізнявся розумом, глибокою науковою ерудицією, цікавився соціально-політичним життям Галичини. Він один 3 перших хто поставив питання про об'єктивне висвітлення причин експлуатації, на фрактах показавши ріст класової нерівності на Галичині. В. Навроцький в літературній діяльності виступав, перш за все, як економіст, демографр та етнографр. Однак, зазначає О. Лисенко, в його економічних та демографічних дослідження переважали думки про властивос- ті історичного процесу «загальні закономірності переходу від одного якісного стану суспільства до іншого, про спадкоємний характер в розвитку соціально-економічних устроїв, ролі в житті суспільства передових, відображаючих інтереси більшості, ідей [5, с. 52].

В цілому, О. Лисенко робить висновок, що спираючись на західноєвропейський визвольний рух С. Подолинському, I. Франку, М. Павліку, О. Терлецькому, частково М. Драгоманову і М. Зіберу, вдалось зробити вирішальний крок в подоланні ідеалізму в поглядах на суспільство та прийти до думки про головну роль матеріальних фракторів у історичному процесі. Вони висловлювали свої думки стосовно розуміння прогресу як прояву об'єктивних закономірностей поступального розвитку природи та суспільства, прагнули поставити людину та суспільство в центрі уваги при вивченні історичного процесу та перспектив його розвитку [5, с. 20]. У підсумку, зазначав О. Лисенко, ідеї прогресивного, поступального розвитку С. Подолинського, I. Франка та М. Драгоманова переросли в закінчені концепщії, а у О. Терлецького, М. Павліка та М. Зібера стали логічним продовженням їхніх попередніх прогресивних поглядів на історичний процес.

Узагальнюючи результати проведеного аналізу можна стверджувати, що в цілому, незважаючи на різноманітні погляди на суспільний прогрес, ідейні та теоретико-методологічні розбіжності в поглядах українських мислителів, письменників, публіцистів, економістів, соціологів XIX ст., їх об'єднувало те, що їхні спільні інтенції були спрямовані на сприяння визвольного руху в країні, на вивчення і розвиток dрілософрської та суспільно-політичної думки на У країні.

Висновки. Підводячи підсумок дослідження наукового спадку О. Лисенка, слід відмітити наступне: вченим був зроблений конкретний аналіз фрілософрсько-економічної, літературнокритичної та публіцистичної спадщини представників української інтелігенції - I. Франка, С. Подолинського, М. Павліка, О. Терлецького, М. Драгоманова, М. Зібера, В. Навроцького; показана важлива роль передової суспільної думки України другої половини XIX ст., підкреслено їі важливість, як одніеї з ланок духовної культури людства, а також їі великої ролі в постановці та розвитку питань суспільного розвитку і сприяння визвольної боротьби не тільки на Україні, а й в ряді слов'янських країн [5, с. 63]. I хоча свої дослідження ідей та окремих концепцій соціального прогресу другої половини XIX ст. О. Лисенко проводив виходячи 3 положень марксистської фрілософрiї, його спроби по-новому переосмислити, який вплив на розвиток передової суспільної думки, мали видатні діячі та мислителі другої половини XIX ст. на Україні, є досить вагомими. Адже, О. Лисенко намагався донести до широкого загалу те, що теоретична думка про прогрес не стояла на місці, вона рухалась шляхом досягнення істини, вона мала безсумнівні здобутки, які відповідали завданням визвольного руху, а подекуди ці ідеї виростали в закінчені концепції, ставали логічним продовженням попередніх прогресивних поглядів на історичний процес, який пов'язувався 3 досягненнями економічної та духовної свободи. 


\section{Список літератури:}

1. Ярмоліцька Н., Москальчук М. Науково-технічна революція та соціальний аспект матеріального і духовного у розвитку особистості в наукових дослідженнях О. Лисенка в радянський період. Молодий вчений. 2020. № 10(86). C. 304-309.

2. Вілков В.Ю., Ярмоліцька Н.В. «Світоглядно-антропологічний поворот» у дослідженнях українських фрілософрів другої половини XX століття: альтернативні історико-фрілософоські наративи в пострадянській Україні. Annali d'Italia. Scientific Journal of Italy. 2020. № 9(2). C. 39-55.

3. Лисенко О.Я. Соціально-фрілософські проблеми науково-технічної революції. Київ : Т-во «Знання» УРСР, 1974. 63 с.

4. Лысенко А.А. Социологические взгляды И.Я. Франко : авторефр. на соискание уч. степени кандидата филос. н. Москва, 1956. 13 с.

5. Лысенко А.А. Проблема социального прогресса в философрской и общественно-политической мысли Украины второй половины XIX века : автореферат на соискание ученой степени доктора филос. наук, специальность 622 - история фолософии. Киев, 1968. 76 с.

6. Конверський А.Є., Бичко I.В., Огородник I.В. Філософська думка у Київському університеті: історія і сучасність / За заг. ред. профр. А.Є. Конверського. Київ : Центр навчальної літератури, 2005. 336 с.

7. Огородник І.В., Русин М.Ю. Українська фрілософрія в іменах / За ред. М.Ф. Тарасенка. Київ : Либідь, 1997. 328 с.

8. Sergii Rudenko, Iryna Liashenko. Chinese Studies in Ukrainian Philosophy of the Soviet Period. STUDIA WARMINSKIE. 2020. № 57. p. 85-101.

\section{References:}

1. Yarmolitska N., Moskalchuk M. (2020) Naukovo-tekhnichna revoliutsiia ta sotsialnyi aspekt materialnoho i dukhovnoho u rozvytku osobystosti v naukovykh doslidzhenniakh O. Lysenka v radianskyi period [Scientific and technical revolution and the social aspect of the material and spiritual in the development of personality in the scientific research of O. Lysenko in the Soviet period]. Molodyi vchenyi, no. 10(86), pp. 304-309.

2. Vilkov V., Yarmolitska N. (2020) «Svitohliadno-antropolohichnyi povorot» u doslidzhenniakh ukrainskykh filosofiv druhoi polovyny XX stolittia: alternatyvni istoryko-filosofski naratyvy v postradianskii Ukraini [«Worldview and anthropological turn» in the studies of Ukrainian philosophers of the second half of the twentieth century: alternative historical and philosophical narratives in post-Soviet Ukraine]. Annali d'Italia. Scientific Journal of Italy, no. 9(2), pp. 39-55. (in Ukrainian)

3. Lysenko O. (1974) Sotsialno-filosofski problemy naukovo-tekhnichnoi revoliutsii [Socio-philosophical problems of the scientific and technological revolution]. Kyiv: T-vo «Znannia» URSR. (in Ukrainian)

4. Lysenko A.A. (1956) Sociologicheskie vzglyady I.Ya. Franko [Sociological views of I.Ya. Franko]: avtoref. na soiskanie uch. stepeni kandidata filos. n. Moscow. (in Russian)

5. Lysenko A.A. (1968) Problema social'nogo progressa v filosofskoj i obshchestvenno-politicheskoj mysli Ukrainy vtoroj poloviny XIX veka [The problem of social progress in the philosophical and socio-political thought of Ukraine in the second half of the 19th century]: avtoreferat na soiskanie uchenoj stepeni doktora filos. nauk, special'nost' 622 - istoriya filosofii. Kiev. (in Russian)

6. Konverskyj A.Ye., Bychko I.V., Ogorodnyk I.V. (2005) Filosofska dumka u Kyyivskomu universyteti: istoriya i suchasnist [Philosophical Thought at Kyiv University: History and Modernity] / Za zag. red. prof. A.Ye. Konverskogo. Kyiv: Centr navchalnoyi literatury. (in Ukrainian)

7. Ogorodnyk I.V., Rusyn M.Yu. (1997) Ukrayinska filosofiya v imenax [Ukrainian philosophy in names] / Za red. M.F. Tarasenka. Kyiv: Lybid. (in Ukrainian)

8. Sergii Rudenko, Iryna Liashenko (2020) Chinese Studies in Ukrainian Philosophy of the Soviet Period. STUDIA WARMIŃSKIE, no. 57, p. 85-101. 